\title{
Angucycline Glycosides from Mangrove-Derived Streptomyces diastaticus subsp. SCSIO GJ056
}

\author{
Chun Gui ${ }^{1,2}(\mathbb{D})$, Yena Liu ${ }^{3}$, Zhenbin Zhou ${ }^{1,2}$, Shanwen Zhang ${ }^{1,2}$, Yunfeng Hu ${ }^{1}$, Yu-Cheng Gu ${ }^{4}$, \\ Hongbo Huang ${ }^{1, *}$ and Jianhua $\mathrm{Ju}^{1,2, *}$ \\ 1 CAS Key Laboratory of Tropical Marine Bio-resources and Ecology, Guangdong Key Laboratory of Marine \\ Materia Medica, RNAM Center for Marine Microbiology, South China Sea Institute of Oceanology, Chinese \\ Academy of Sciences, 164 West Xingang Road, Guangzhou 510301, China; guichun1988@sina.com (C.G.); \\ zzb1881396@163.com (Z.Z.); sherry920111@163.com (S.Z.); yunfeng.hu@scsio.ac.cn (Y.H.) \\ 2 University of Chinese Academy of Sciences, 19 Yuquan Road, Beijing 110039, China \\ 3 State Key Laboratory of Oncology in South China, Collaborative Innovation Center for Cancer Medicine, \\ Sun Yat-Sen University Cancer Center, Guangzhou 510060, China; LIUYN@sysucc.org.cn \\ 4 Syngenta Jealott's Hill International Research Centre, Bracknell, Berkshire RG42 6EY, UK; \\ yucheng.gu@syngenta.com \\ * Correspondence: huanghb@scsio.ac.cn (H.H.); jju@scsio.ac.cn (J.J.); Tel./Fax: +86-20-3406-6449 (H.H.); \\ Tel./Fax: +86-20-8902-3028 (J.J.)
}

Received: 15 May 2018; Accepted: 25 May 2018; Published: 28 May 2018

\begin{abstract}
Nine new angucycline glycosides designated urdamycins N1-N9 (1-9), together with two known congener urdamycins A (10) and B (11), were obtained from a mangrove-derived Streptomyces diastaticus subsp. SCSIO GJ056. The structures of new compounds were elucidated on the basis of extensive spectroscopic data analysis. The absolute configurations of 6-9 were assigned by electronic circular dichroism calculation method. Urdamycins N7 (7) and N8 (8) represent the first naturally occurring $(5 R, 6 R)$-angucycline glycosides, which are diastereomers of urdamycins N6 (6) and N9 (9), respectively.
\end{abstract}

Keywords: mangrove-derived Streptomyces; angucycline; urdamycin

\section{Introduction}

The angucycline group members are type II polyketide derived metabolites obtained exclusively from actinomycetes [1-3]. Angucycline compounds exhibited various bioactivities, including antitumor, cytostatic, enzyme inhibition, antibacterial, antiviral, and inhibition of platelet aggregation function [4-7].

During the course of searching for novel anti-infective and antitumor agents from the marine environment, we found that the chemical profile of strain SCSIO GJ056 cultivated in AM2 medium revealed an array of secondary metabolites showing typical UV/VIS absorptions, which were similar to those of angucyclines/anthracyclines. Subsequent solvent extraction and isolation procedures led to the purification and structure elucidation of nine new angucycline glycosides, named urdamycins N1-N9 (1-9), together with two known urdamycins A (10) and B (11). Urdamycins N7 (7) and N8 (8) represent the first naturally occurring $(5 R, 6 R)$-angucycline glycosides. Herein, we report the fermentation, isolation, and structure elucidation of these compounds.

\section{Results and Discussion}

The strain SCSIO GJ056 was fermented (15 L) and the fermentation broth was extracted with butanone. The extract was subjected to repetitive silica gel column chromatography, followed by preparative HPLC purification to yield compounds 1-11 (Figure 1). The known urdamycins A (10) 
and B (11) were identified by comparisons of MS, ${ }^{1} \mathrm{H}$, and ${ }^{13} \mathrm{C}$ NMR spectroscopic data with those previously reported [8].

Compound 1 was obtained as a yellowish powder. Its molecular formula was determined to be $\mathrm{C}_{38} \mathrm{H}_{46} \mathrm{O}_{14}$ on the basis of HRESIMS peak at $m / z 725.2834[\mathrm{M}-\mathrm{H}]^{-}$, indicating 16 degrees of unsaturation. The ${ }^{13} \mathrm{C}$ and DEPT NMR spectra of 1 displayed 38 carbon resonances, including five methyls, six methylenes, 14 methines, and 13 nonprotonated carbons. The ${ }^{1} \mathrm{H}$ NMR spectrum showed one chelated hydroxy group signal at $\delta_{\mathrm{H}} 12.55(1 \mathrm{H}, \mathrm{br} \mathrm{s}, 8-\mathrm{OH})$, a pair of ortho-coupled aromatic proton signals at $\delta_{\mathrm{H}} 7.81(\mathrm{~d}, 7.8 \mathrm{~Hz}, \mathrm{H}-10)$ and $7.59(\mathrm{~d}, 7.8 \mathrm{~Hz}, \mathrm{H}-11)$, and a singlet aromatic proton signal at $\delta_{\mathrm{H}} 7.65$ (s, H-6). The HMBC correlations (Figure 2) from H-6 to C-4a, C-5, C-7, and C-12a, from $\mathrm{H}-11$ to $\mathrm{C}-7 \mathrm{a}, \mathrm{C}-9$, and $\mathrm{C}-12$, and from $\mathrm{H}-10$ to C-8, C-9, and C-11a confirmed the existence of the anthraquinone skeleton (rings $B, C$, and D). Further HMBC correlations of $\mathrm{H}_{2}-2 / C-1, C-12 b, C-4$; $\mathrm{H}_{2}-4 / \mathrm{C}-2, \mathrm{C}-4 \mathrm{a}, \mathrm{C}-12 \mathrm{~b}$; and $\mathrm{H}_{3}-13 / \mathrm{C}-2, \mathrm{C}-3, \mathrm{C}-4$ allowed the assignment of the angular ring (ring A) with a methyl group $\left(\mathrm{CH}_{3}-13\right)$ substitution at $\mathrm{C}-3$. A methoxy group $\left(\mathrm{OCH}_{3}-14\right)$ attached at $\mathrm{C}-5$ in ring $\mathrm{B}$ was deduced by the $\mathrm{HMBC}$ correlation of $\mathrm{H}_{3}-14 / \mathrm{C}-5$. A hydroxy group linked at $\mathrm{C}-3$ in ring $\mathrm{A}$ was inferred based on the ${ }^{13} \mathrm{C}$ NMR chemical shift at $\delta_{\mathrm{C}} 71.8$. The absolute configuration of $\mathrm{C}-3$ was tentatively deduced to be $R$, which was identical with that of urdamycinone B and N05WA963D in light of the similar ${ }^{13} \mathrm{C}$ NMR resonances of $\mathrm{C}-3$ and $\mathrm{CH}_{3}-13$, as well as the similar biosynthetic pathway [8,9].

In addition, three anomeric methine signals at $\delta_{\mathrm{H}} 4.82$ and $\delta_{\mathrm{C}} 71.1\left(\mathrm{CH}-1^{\prime}\right), \delta_{\mathrm{H}} 4.96$ and $\delta_{\mathrm{C}}$ $97.4\left(\mathrm{CH}-1^{\prime \prime}\right)$, and $\delta_{\mathrm{H}} 4.45$ and $\delta_{\mathrm{C}} 101.5\left(\mathrm{CH}-1^{\prime \prime \prime}\right)$, together with three doublet methyl signals at $\delta_{\mathrm{H}} 1.37\left(\mathrm{CH}_{3}-6^{\prime}\right), \delta_{\mathrm{H}} 1.16\left(\mathrm{CH}_{3}-6^{\prime \prime}\right)$, and $\delta_{\mathrm{H}} 1.23\left(\mathrm{CH}_{3}-6^{\prime \prime \prime}\right)$ revealed the presence of a trisaccharide moiety consisting of three deoxy sugars in 1 . The ${ }^{1} \mathrm{H}-{ }^{1} \mathrm{H}$ COSY spectrum allowed the full assignment of the sugar moieties from $\mathrm{CH}-1^{\prime}$ to $\mathrm{CH}_{3}-6^{\prime}$, from $\mathrm{CH}-1^{\prime \prime}$ to $\mathrm{CH}_{3}-6^{\prime \prime}$, and from $\mathrm{CH}-1^{\prime \prime \prime}$ to $\mathrm{CH}_{3}-6^{\prime \prime \prime}$. The HMBC correlations of $\mathrm{H}-3^{\prime} / \mathrm{C}-1^{\prime \prime}$ and $\mathrm{H}-4^{\prime \prime} / \mathrm{C}-1^{\prime \prime \prime}$ confirmed the existence of a $\beta$-olivose-( $1 \rightarrow 4)-\alpha$-rhodinose- $(1 \rightarrow 3)$ - $\beta$-olivosyl unit. This trisaccharide was connected with the aglycone at $\mathrm{C}-9$ based on the HMBC correlations of $\mathrm{H}-1^{\prime} / \mathrm{C}-9$ and $\mathrm{H}-9 / \mathrm{C}-1^{\prime}$. The relative configuration of the trisaccharide moiety was deduced by ${ }^{1} \mathrm{H}_{-}{ }^{1} \mathrm{H}$ coupling constants (Table 1 ) and NOE experiment (Figure 3). Detailed comparisons showed that the ${ }^{1} \mathrm{H}$ and ${ }^{13} \mathrm{C}$ NMR spectroscopic data of the sugar units were almost identical with those in urdamycin A [10,11]. Thus, the structure of $\mathbf{1}$ was determined and named urdamycin N1.

Compound 2, isolated as a dark red powder, has the molecular formula of $\mathrm{C}_{38} \mathrm{H}_{44} \mathrm{O}_{13}$ on the basis of HRESIMS peak at $m / z 707.2708[\mathrm{M}-\mathrm{H}]^{-}$, showing 17 degrees of unsaturation and an $18 \mathrm{amu}$ less than that of compound $\mathbf{1}$. An obvious red shift on the UV-VIS spectrum of $\mathbf{2}$ relative to that of $\mathbf{1}$ indicated an additional conjugated system in 2 . The ${ }^{13} \mathrm{C}$ and DEPT NMR data of $\mathbf{2}$ displayed 38 carbon signals attributable to five methyls, four methylenes, 16 methines, and 13 nonprotonated carbons. The ${ }^{1} \mathrm{H}$ and HSQC NMR spectra suggested three singlet olefnic proton signals at $\delta_{\mathrm{H}} 7.58(\mathrm{H}-4), \delta_{\mathrm{H}}$ $7.54(\mathrm{H}-6)$, and $\delta_{\mathrm{H}} 6.99(\mathrm{H}-2)$, and a pair of ortho-coupled aromatic proton signals at $\delta_{\mathrm{H}} 7.82(\mathrm{~d}, 7.6 \mathrm{~Hz}$, $\mathrm{H}-10)$ and $7.68(\mathrm{~d}, 7.6 \mathrm{~Hz}, \mathrm{H}-11)$. Comparing the ${ }^{1} \mathrm{H}$ and ${ }^{13} \mathrm{C}$ NMR spectroscopic data to those of 1 revealed that $\mathbf{2}$ possessed a similar core structure with that of $\mathbf{1}$. The difference between $\mathbf{2}$ and $\mathbf{1}$ was the aromatization of ring $\mathrm{A}$ in 2, which supported by the $\mathrm{HMBC}$ correlations from $\mathrm{CH}_{3}-13$ to $\mathrm{C}-2, \mathrm{C}-3$, and C-4, from H-2 to C-1, C-4, and C-12b, and from H-4 to C-2, C-4a, and C-12b. Compound 2 possessed the same trisaccharide moiety with $\mathbf{1}$ according to similar ${ }^{1} \mathrm{H}$ and ${ }^{13} \mathrm{C}$ NMR signals in aliphatic area. The structure of 2 was elucidated as shown in Figure 1 by detailed analysis of 2D NMR spectra data.

Compound 3, a dark green powder, was isolated as minor component from the extract. Its molecular formula of $\mathrm{C}_{26} \mathrm{H}_{24} \mathrm{O}_{8}$ was determined by the HRESIMS peak at $m / z 463.1409[\mathrm{M}-\mathrm{H}]^{-}$, indicating 15 degrees of unsaturation. Comprehensive analysis of its ${ }^{1} \mathrm{H}$ and ${ }^{13} \mathrm{C}$ NMR spectroscopic data revealed that 3 had the same aglycone with that of 2 . However, a set of ${ }^{1} \mathrm{H}$ and ${ }^{13} \mathrm{C}$ resonances ascribed to $\beta$-olivose-( $1 \rightarrow 4)$ - $\alpha$-rhodinosyl moiety disappeared, indicating the absence of two sugar units in 3. This is consistent with the HRESIMS data, which showing a $\mathrm{C}_{12} \mathrm{H}_{20} \mathrm{O}_{5}$ fragment loss relative to 2 . Therefore, the structure of $\mathbf{3}$ was established and named urdamycin N3. 

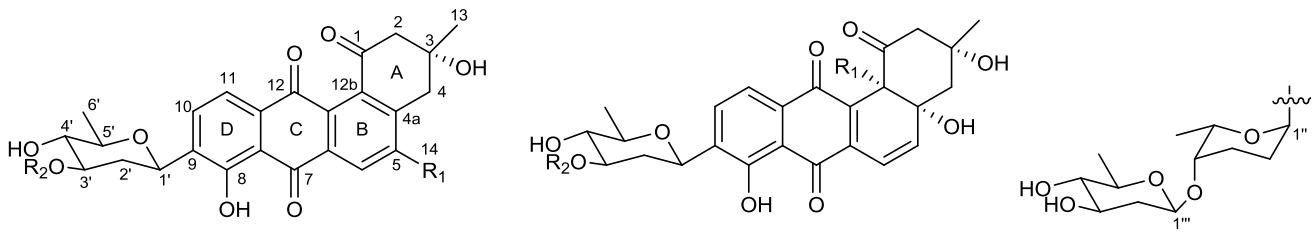

$$
\begin{aligned}
& 1 \mathrm{R}_{1}=\mathrm{OMe}, \mathrm{R}_{2}=\text { I } \\
& 11 \mathrm{R}_{1}=\mathrm{H}, \mathrm{R}_{2}=\text { I }
\end{aligned}
$$
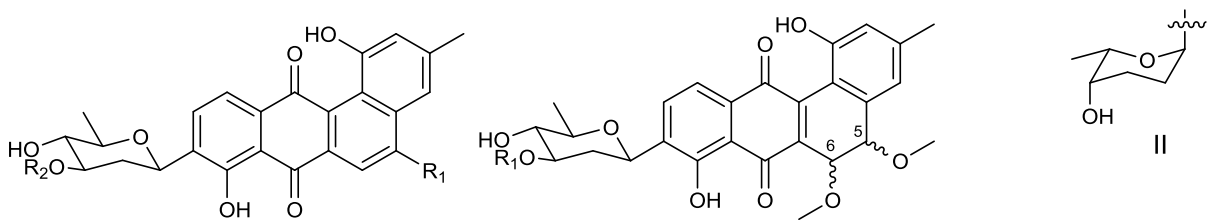

$$
\begin{array}{ll}
2 \mathrm{R}_{1}=\mathrm{OMe}, \mathrm{R}_{2}=1 \\
3 \mathrm{R}_{1}=\mathrm{OMe}, \mathrm{R}_{2}=\mathrm{H} \\
4 \mathrm{R}_{1}=\mathrm{OH}, \mathrm{R}_{2}=1 \\
5 \mathrm{R}_{1}=\mathrm{H}, \quad \mathrm{R}_{2}=1
\end{array}
$$$$
65 \mathrm{~S}, 6 \mathrm{~S}, \mathrm{R}_{1}=\mathrm{H}
$$

\begin{tabular}{|c|c|c|c|c|c|c|}
\hline \multirow{2}{*}{ Position } & \multicolumn{2}{|r|}{$1^{a}$} & \multicolumn{2}{|r|}{$2^{b}$} & \multicolumn{2}{|r|}{$3^{c}$} \\
\hline & $\delta_{\mathrm{C}}$ & $\delta_{\mathbf{H}}$ & $\delta_{\mathrm{C}}$ & $\delta_{\mathbf{H}}$ & $\delta_{\mathrm{C}}$ & $\delta_{\mathbf{H}}$ \\
\hline 1 & 198.4 & & 155.3 & & 155.2 & \\
\hline 2 & 53.2 & $2.90, \mathrm{dd}(14,1.1) ; 3.0, \mathrm{~m}$ & 118.7 & $6.99, \mathrm{~s}$ & 118.8 & $6.98, \mathrm{~s}$ \\
\hline 3 & 71.8 & & 140.8 & & 140.9 & \\
\hline 4 & 37.5 & $3.18, \mathrm{~m} ; 2.80, \mathrm{~d}(18.1)$ & 113.0 & $7.58, \mathrm{~s}$ & 113.2 & $7.58, \mathrm{~m}$ \\
\hline $4 a$ & 137.9 & & 126.0 & & 126.0 & \\
\hline 5 & 160.9 & & 160.3 & & 160.5 & \\
\hline 6 & 108.2 & $7.65, \mathrm{~s}$ & 99.8 & $7.54, \mathrm{~s}$ & 100.0 & $7.54, \mathrm{~s}$ \\
\hline $6 a$ & 135.1 & & 135.8 & & 136.1 & \\
\hline 7 & 187.9 & & 187.5 & & 187.6 & \\
\hline $7 a$ & 114.8 & & 113.9 & & 114.1 & \\
\hline 8 & 158.0 & & 156.8 & & 157.0 & \\
\hline 9 & 136.6 & & 136.8 & & 137.3 & \\
\hline 10 & 133.9 & $7.81, \mathrm{~d}(7.8)$ & 133.4 & $7.82, \mathrm{~d}(7.6)$ & 133.3 & $7.80, \mathrm{~m}$ \\
\hline 11 & 119.5 & $7.59, \mathrm{~d}(7.8)$ & 119.9 & $7.68, \mathrm{~d}(7.6)$ & 120.0 & $7.67, \mathrm{~m}$ \\
\hline $11 \mathrm{a}$ & 133.8 & & 133.7 & & 133.8 & \\
\hline 12 & 182.3 & & 185.6 & & 186.0 & \\
\hline $12 \mathrm{a}$ & 128.4 & & 129.8 & & 129.9 & \\
\hline $12 b$ & 137.4 & & 120.4 & & 120.5 & \\
\hline 13 & 30.1 & $1.42, \mathrm{~s}$ & 21.2 & $2.42, \mathrm{~s}$ & 21.2 & $2.41, \mathrm{~s}$ \\
\hline 14 & 56.5 & $3.99, \mathrm{~s}$ & 56.6 & $4.14, \mathrm{~s}$ & 56.6 & $4.13, \mathrm{~s}$ \\
\hline $1^{\prime}$ & 71.1 & $4.82, \mathrm{~d}(10.6)$ & 70.4 & $4.8, \mathrm{~d}(13.7)$ & 70.8 & $4.78, \mathrm{~d}(10.9)$ \\
\hline \multirow[t]{2}{*}{$2^{\prime}$} & 37.6 & $1.41, \mathrm{~m}$ & 39.7 & $1.35, \mathrm{~m}$ & 40.0 & 1.31, dd (11.4) \\
\hline & & $2.42, \mathrm{dd}(12.3,4.2)$ & & $2.01, \mathrm{~m}$ & & $2.28, \mathrm{~d}(10.2)$ \\
\hline $3^{\prime}$ & 81.6 & 3.67, ddd $(11.4,8.4,5.1)$ & 74.6 & 3.69, ddd $(11.1,8.9,4.9)$ & 71.7 & $3.55, \mathrm{t}(11.8)$ \\
\hline $4^{\prime}$ & 76.0 & $3.13, \mathrm{~m}$ & 74.5 & $3.06, \operatorname{td}(8.9,5.4)$ & 77.1 & $2.90, \mathrm{t}(8.8)$ \\
\hline $5^{\prime}$ & 76.1 & $3.45, \mathrm{~m}$ & 76.2 & $3.47, \mathrm{q}(6.0)$ & 76.3 & $3.38, \mathrm{~m}$ \\
\hline $6^{\prime}$ & 18.4 & 1.37, d (6.1) & 18.5 & $1.30, \mathrm{~d}(6.1)$ & 18.5 & $1.28, \mathrm{~d}(6.1)$ \\
\hline $1^{\prime \prime}$ & 97.4 & $4.96, \mathrm{~s}$ & 91.9 & $4.90, \mathrm{~d}(2.3)$ & & \\
\hline \multirow[t]{2}{*}{$2^{\prime \prime}$} & 25.1 & $1.47, \mathrm{~m}$ & 24.1 & $1.29, \mathrm{~m}$ & & \\
\hline & & $2.06, \mathrm{~m}$ & & $1.83, \mathrm{~m}$ & & \\
\hline $3^{\prime \prime}$ & 24.5 & $1.9, \mathrm{~m}$ & 24.1 & $1.76, \mathrm{~m} ; 1.95, \mathrm{~m}$ & & \\
\hline $4^{\prime \prime}$ & 76.2 & $3.49, \mathrm{~m}$ & 75.4 & $3.44, \mathrm{~m}$ & & \\
\hline $5^{\prime \prime}$ & 67.5 & $4.09, \mathrm{~m}$ & 65.3 & $4.15, \mathrm{~m}$ & & \\
\hline $6^{\prime \prime}$ & 16.9 & $1.16, \mathrm{~d}(6.5)$ & 17.0 & $1.05, \mathrm{~d}(6.5)$ & & \\
\hline $1^{\prime \prime \prime}$ & 101.5 & $4.45, \mathrm{dd}(9.7,1.5)$ & 101.0 & 4.48, dd $(9.7,1.6)$ & & \\
\hline \multirow[t]{2}{*}{$2^{\prime \prime \prime}$} & 38.9 & 2.19, ddd $(12.5,4.8,1.5)$ & 36.0 & $1.24, \mathrm{~m}$ & & \\
\hline & & $1.60, \operatorname{td}(12.1,10.0)$ & & $2.47, \mathrm{~m}$ & & \\
\hline $3^{\prime \prime \prime}$ & 71.4 & $3.45, \mathrm{~m}$ & 70.3 & $3.33, \mathrm{~m}$ & & \\
\hline $4^{\prime \prime \prime}$ & 77.0 & $2.95, \mathrm{t}(8.9)$ & 76.8 & $2.72, \mathrm{~m}$ & & \\
\hline $5^{\prime \prime \prime}$ & 71.7 & $3.16, \mathrm{~m}$ & 71.6 & $3.11, \mathrm{dq}(9.0,6.2)$ & & \\
\hline $6^{\prime \prime \prime}$ & 17.7 & $1.23, \mathrm{~d}(6.2)$ & 18.2 & $1.14, \mathrm{~d}(6.2)$ & & \\
\hline
\end{tabular}$$
75 R, 6 R, \mathrm{R}_{1}=\mathrm{H}
$$$$
85 R, 6 R, \mathrm{R}_{1}=1
$$

$95 \mathrm{~S}, 6 \mathrm{~S}, \mathrm{R}_{1}=1$

Figure 1. Structures of compounds 1-11.

Table 1. The ${ }^{1} \mathrm{H}$ and ${ }^{13} \mathrm{C}$ NMR data of compounds $1-3$ ( $\delta$ in ppm, $J$ in $\mathrm{Hz}$ ).

${ }^{a}$ Recorded in $\mathrm{CDCl}_{3}-\mathrm{CD}_{3} \mathrm{OD}(9: 1) ;{ }^{\mathrm{b}}$ Recorded in DMSO; ${ }^{\mathrm{c}}$ Recorded in DMSO-CD ${ }_{3} \mathrm{OD}$ (9:1). 
Compound 4 was obtained as a dark green powder. Its molecular formula was determined to be $\mathrm{C}_{37} \mathrm{H}_{42} \mathrm{O}_{13}$ by the HRESIMS peak at $\mathrm{m} / z$ 693.2554 [M - H] ${ }^{-}$. The ${ }^{1} \mathrm{H}$ and ${ }^{13} \mathrm{C}$ NMR data of 4 were closely similar to those of 2, except that the methoxy signals at $\delta_{\mathrm{H}} 4.14, \delta_{\mathrm{C}} 56.6$ in 2 were absent. The ${ }^{13} \mathrm{C}$ NMR signal of C-5 shifted from $\delta_{\mathrm{C}} 160.3$ in 2 to $\delta_{\mathrm{C}} 163.6$ in 4, indicating the OMe-5 in 2 was replaced by $\mathrm{OH}-5$ in 4 . Compound 4 was named urdamycin $\mathrm{N} 4$.

Compound 5 was obtained as a red powder. The molecular formula of $\mathrm{C}_{37} \mathrm{H}_{42} \mathrm{O}_{12}$, as determined by HRESIMS, which was one oxygen atom less than that of 4 . The ${ }^{1} \mathrm{H}$ and ${ }^{13} \mathrm{C}$ NMR spectroscopic data were similar with those of $\mathbf{4}$, except that two pairs of ortho-coupled aromatic signals were observed. Additionally, the ${ }^{13} \mathrm{C}$ NMR signal at $\delta_{\mathrm{C}} 163.6$ for the oxygen-bearing aromatic C-5 in 4 was replaced by an aromatic methine signal at $\delta_{\mathrm{C}} 135.4$. Thus, the structure of 5 was determined as 5-demethoxy-urdamycin N2, designated as urdamycin N5.

The molecular formulae of compounds 6 and 7 were determined both to be $\mathrm{C}_{27} \mathrm{H}_{28} \mathrm{O}_{9}$ by HRESIMS, indicating 14 degrees of unsaturation. The ${ }^{1} \mathrm{H}$ and ${ }^{13} \mathrm{C}$ NMR spectroscopic data of 6 were similar with those of 3, except that two aromatic carbon signals at $\delta_{C} 160.5$ (C-5) and 100.0 (C-6) in 3 were replaced by two oxygen-bearing methine carbon signals at $\delta_{C} 78.1(\mathrm{C}-5)$ and 70.2 (C-6). Furthermore, two methoxys were attached at C- 5 and C- 6 based on the HMBC correlations of $\mathrm{H}_{3}-14 / \mathrm{C}-5$ and $\mathrm{H}_{3}-15 / \mathrm{C}-6$, respectively. Small coupling constants $(2.8 \mathrm{~Hz}$ ) between $\mathrm{H}-5$ and H-6 revealed a trans configuration of $\mathrm{H}-5$ and $\mathrm{H}-6$, indicating an $(5 R, 6 R)$ or $(5 S, 6 S)$ configuration of 6 . To determine the absolute configurations of $\mathbf{6}$, comparisons of the experimental and ECD spectra using a time-dependent density functional theory (TDDFT) were employed. Comparison of the experimental and calculated CD spectra (Figure 4 ) established the absolute configuration as $(5 S, 6 S)$ for 6 , which were the same as those of PMO70747, PD116740, and TAN-1085 [12-17]. Compound 7 possessed the same planar structure with that of $\mathbf{6}$, as deduced by the COSY and HMBC spectra (Figure 2). However, the experimental and calculated CD spectra of 7 showed cotton effects totally opposite to those of $\mathbf{6}$, respectively, inferring the $(5 R, 6 R)$ configuration for 7 (Figure 4). Compounds $\mathbf{6}$ and $\mathbf{7}$ were named urdamycins N6 and N7, respectively.

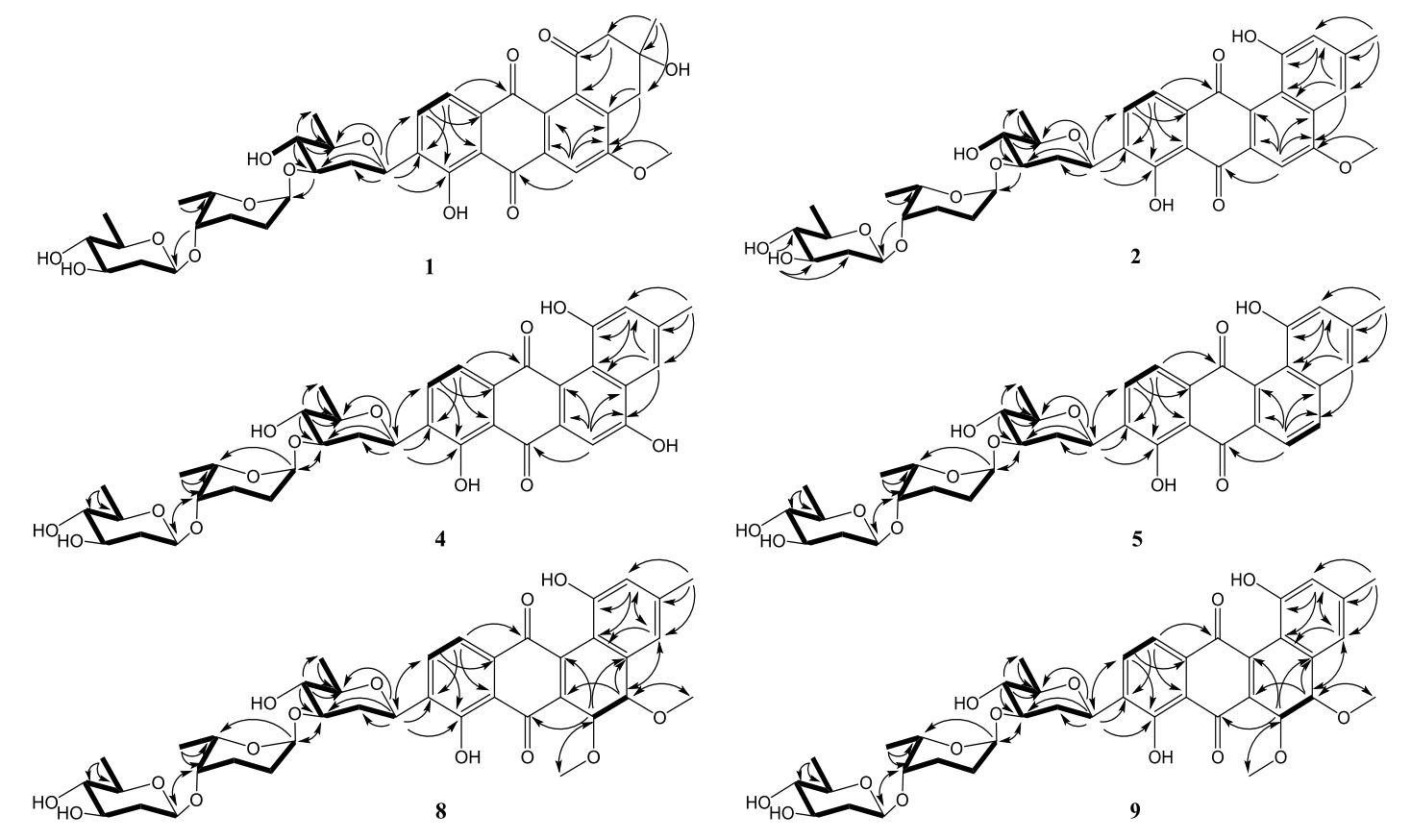

Figure 2. Cont. 

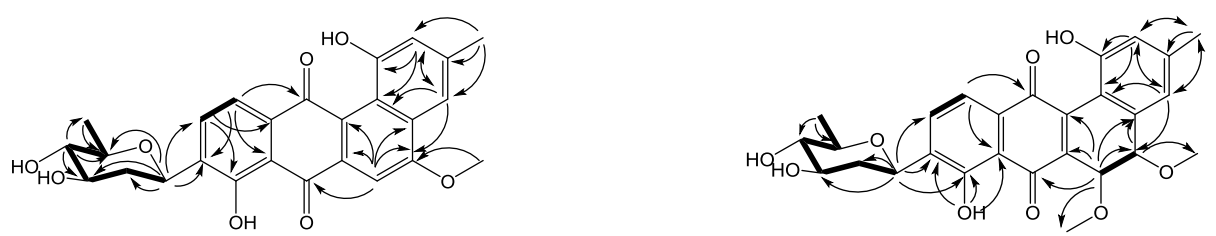

3

6

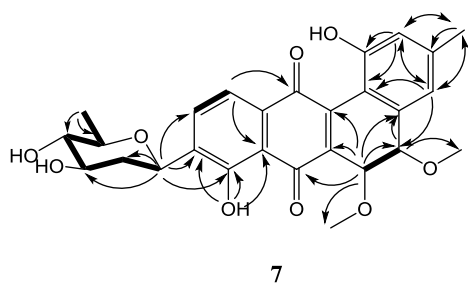

Figure 2. COSY (bold) and selected HMBC (arrow) correlations for 1-9.
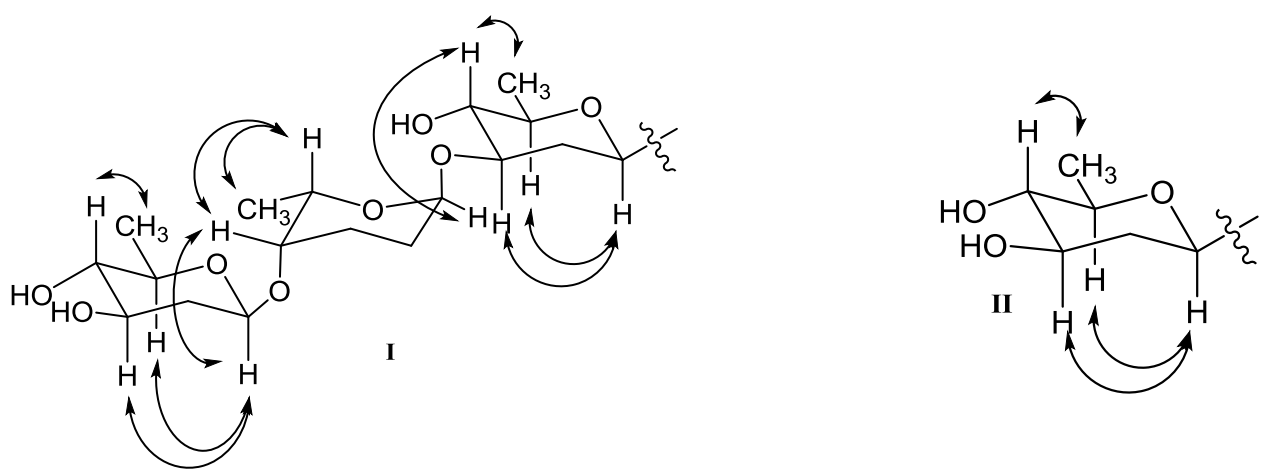

Figure 3. Key NOESY correlations of $\beta$-olivose-( $1 \rightarrow 4)$ - $\alpha$-rhodinose- $(1 \rightarrow 3)-\beta$-olivose in $\mathbf{1}, \mathbf{2}, \mathbf{4}, \mathbf{5}, \mathbf{8}$, and 9 (I), and $\beta$-olivose in 3, 6 and 7 (II).

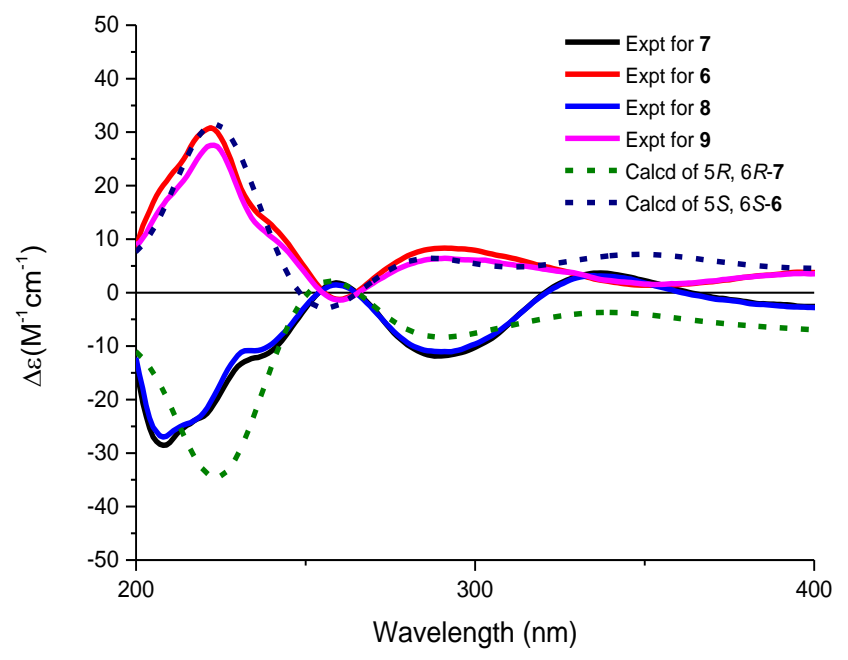

Figure 4. Experimental and calculated ECD spectra of 6-9 in methanol.

Compounds $\mathbf{8}$ and $\mathbf{9}$ were isolated as red powder, both had the same molecular formula of $\mathrm{C}_{39} \mathrm{H}_{48} \mathrm{O}_{14}$ as determined by HRESIMS. The ${ }^{1} \mathrm{H}$ and ${ }^{13} \mathrm{C}$ NMR spectroscopic data of 8 and 9 resembled those of 2, except that two aromatic carbon signals at $\delta_{\mathrm{C}} 160.3$ (C-5) and 99.8 (C-6) in 2 were replaced by two oxygen-bearing methine carbon signals at $\delta_{\mathrm{C}} 80.0$ (C-5) and $67.4(\mathrm{C}-6)$ in 8 , and at $\delta_{\mathrm{C}} 78.1$ (C-5) and 70.2 (C-6) in 9. Two methoxys were attached at C-5 and C-6 in 8 and $\mathbf{9}$ based on the HMBC correlations 
of $\mathrm{H}_{3}-14 / \mathrm{C}-5$ and $\mathrm{H}_{3}-15 / \mathrm{C}-6$, respectively. Small coupling constants of $\mathrm{H} 5 / \mathrm{H} 6$ revealed the both trans configurations in compounds 8 and 9 . The absolute configurations were determined to be $(5 R, 6 R)$ for 8 and $(5 S, 6 S)$ for 9 by comparing their CD curve to those of 7 and 6 , respectively (Figure 4). Finally, compounds 8 and 9 were elucidated and named urdamycin N8 and urdamycin N9, respectively. Compounds 7 and 8 represent the first naturally occurring $(5 R, 6 R)$-angucycline metabolite.

\section{Experimental Section}

\subsection{General Experimental Procedures}

Column chromatography (CC) was performed using silica gel (100-200 mesh; Jiangpeng Silica gel development, Inc., Shandong, China). Thin layer chromatography (TLC) was conducted with precoated glass plates $\left(0.1-0.2 \mathrm{~mm}\right.$; silica gel $\mathrm{GF}_{254}, 10-40 \mathrm{~nm}$, Jiangpeng, China). HPLC analyses were performed with a 1260 infinity system (Agilent, Santa Clara, CA, USA) using a Phenomenex Prodigy ODS (2) column $(150 \times 4.6 \mathrm{~mm}, 5 \mu \mathrm{m}$; USA). Semi-preparative HPLC were performed with a Primaide 1110 solvent delivery module equipped with a 1430 photodiode array detector (Hitachi, Tokyo, Japan), using a YMC-Pack ODS-A column (250 mm $\times 10$ mm, $5 \mu \mathrm{m}$; YMC Co., Ltd., Kyoto, Japan). UV spectra were recorded on a U-2910 spectrometer (Shimadzu, Kyoto, Japan); IR spectra were obtained on an IRAffinity-1 spectrophotometer (Shimadzu, Kyoto, Japan). CD spectra were measured on a Chirascan circular dichroism spectrometer (Applied Photophysics, Leatherhead, UK). High-resolution mass spectral data were obtained on a MaXis Q-TOF mass spectrometer (Bruker, Billerica, MA, USA). Optical rotations were recorded with an MCP-500 polarimeter (Anton Paar, Graz, Austria). NMR spectra were recorded on a Bruker Avance 500 or a Bruker Avance 700 spectrometer (Bruker, Billerica, MA, USA). Carbon signals and the residual proton signals of DMSO- $d_{6}\left(\delta_{\mathrm{C}} 39.52\right.$ and $\left.\delta_{\mathrm{H}} 2.50\right), \mathrm{CD}_{3} \mathrm{OD}\left(\delta_{\mathrm{C}} 49.0\right.$ and $\left.\delta_{\mathrm{H}} 4.87\right)$, and $\mathrm{CDCl}_{3}\left(\delta_{\mathrm{C}} 77.16\right.$ and $\left.\delta_{\mathrm{H}} 7.26\right)$ were used for calibration. Coupling constants $(J)$ are given in $\mathrm{Hz}$.

\subsection{Bacterial Materials}

Strain SCSIO GJ056 was isolated from a mangrove-derived sediment sample collected in Yalong bay, China. It was identified as Streptomyces diastaticus subsp. on the basis of morphological characteristics and 16S rRNA sequence analysis by comparisons with other sequences in the GenBank database. The DNA sequence has been deposited in GenBank (accession no. MH368281). The strain was preserved at the RNAM Center for Marine Microbiology, South China Sea Institute of Oceanology, Chinese Academy of Sciences and also at the China General Microbiological Culture Collection Center (CGMCC, Beijing, China), CGMCC No. 13648.

\subsection{Fermentation, Extraction, and Isolation of the Compounds}

A portion of spore and mycelium mixture of SCSIO GJ056 grown on ISP4 medium agar plates were inoculated into $50 \mathrm{~mL}$ modified AM2 medium $(0.5 \%$ soybean flour, $0.5 \%$ soluble starch, $0.2 \%$ yeast extract, $0.2 \%$ peptone, $2.0 \%$ glucose, $0.05 \% \mathrm{KH}_{2} \mathrm{PO}_{4}, 0.05 \% \mathrm{MgSO}_{4} \cdot 7 \mathrm{H}_{2} \mathrm{O}, 0.4 \% \mathrm{NaCl}$, $0.2 \% \mathrm{CaCO}_{3}, 3.0 \%$ sea salt (Guangdong Province Salt Industry Group, Guangzhou, China), pH 7.2 before sterilization) in $250 \mathrm{~mL}$ Erlenmeyer flasks, and were incubated at $28{ }^{\circ} \mathrm{C}$ on a rotary shaker at $200 \mathrm{rpm}$ for 1.5 days as the seed culture. Then the $50 \mathrm{~mL}$ of culture solution was transferred into a $1 \mathrm{~L}$ Erlenmeyer flask and then incubated at $28{ }^{\circ} \mathrm{C}, 200 \mathrm{rpm}$ for seven days. On the seventh day, the entire culture broth $(15 \mathrm{~L})$ was harvested and centrifuged to yield the mycelial cake and liquid broth. The liquid broth was extracted with butanone for three times, and the mycelial cake was extracted using $1 \mathrm{~L}$ of acetone for three times. The combined organic layers were dried under vacuum to yield a residue. The residue was subjected to silica gel CC using gradient elution with $\mathrm{CHCl}_{3}$ and $\mathrm{MeOH}$ mixtures (100:0, 99:1, 97:3, 95:5, 90:10, 80:20, and 50:50, $v / v)$ to give seven fractions (Fr.A1-Fr.A7). Fr.A1 and Fr.A2 were combined after HPLC analysis and purified by silica gel CC eluting with petroleum ether and EtOAc mixtures (100:0, 90:10, 80:20, 70:30, 60:40, 40:60, 20:80, 0:100, v/v) to give eight 
fractions (Fr.B1-Fr.B8). Fr.B4 was subjected to Sephadex LH-20 CC eluted with $\mathrm{CHCl}_{3} / \mathrm{MeOH}(1: 1)$ to obtain 1 (6 mg). Fr.B5 and Fr.B6 were combined and further purified by semi-preparative HPLC with an ODS column to afford $\mathbf{1 0}(220 \mathrm{mg})$ at $t_{\mathrm{R}} 26 \mathrm{~min}$ and $\mathbf{1 1}(70 \mathrm{mg})$ at $t_{\mathrm{R}} 30 \mathrm{~min}$. Fractions B1 and $\mathrm{B} 2$ were combined and subjected to preparative TLC using $\mathrm{CHCl}_{3} / \mathrm{MeOH}(92: 8)$ to obtain six sub-fractions (Fr.C1-Fr.C6). Fr.C1 was purified by preparative HPLC with an ODS column eluted with $\mathrm{CH}_{3} \mathrm{CN} / \mathrm{H}_{2} \mathrm{O}$ (30:70 to 100:0 over $28 \mathrm{~min}$, then hold $\left.7 \mathrm{~min}, 9 \mathrm{~mL} / \mathrm{min}\right)$ to afford $7(0.6 \mathrm{mg})$ and 6 $(0.6 \mathrm{mg})$ at $t_{\mathrm{R}} 13.5 \mathrm{~min}, 14.5 \mathrm{~min}$, respectively. Fr.C2 was purified by preparative HPLC with an ODS column eluted with $\mathrm{CH}_{3} \mathrm{CN} / \mathrm{H}_{2} \mathrm{O}$ (30:70 to 100:0 over $28 \mathrm{~min}$, then hold $7 \mathrm{~min}, 9 \mathrm{~mL} / \mathrm{min}$ ) to afford 8 $(0.7 \mathrm{mg}), 9(0.6 \mathrm{mg})$, and $5(0.6 \mathrm{mg})$ at $t_{\mathrm{R}} 15.5 \mathrm{~min}, 16.5 \mathrm{~min}$, and $26 \mathrm{~min}$, respectively. Fr.C3 was purified by preparative HPLC with an ODS column eluted with $\mathrm{CH}_{3} \mathrm{CN} / \mathrm{H}_{2} \mathrm{O}$ (30:70 to 100:0 over 28 min, then hold $7 \mathrm{~min}, 9 \mathrm{~mL} / \mathrm{min})$ to afford $2(8 \mathrm{mg})$ and $3(7 \mathrm{mg})$ at $t_{\mathrm{R}} 32 \mathrm{~min}, 32.5 \mathrm{~min}$, respectively. Fr.C6 was purified by preparative HPLC eluted with $\mathrm{CH}_{3} \mathrm{CN} / \mathrm{H}_{2} \mathrm{O}$ (30:70 to 100:0 over $28 \mathrm{~min}$, then held for $7 \mathrm{~min}, 9 \mathrm{~mL} / \mathrm{min})$ to afford $4(8 \mathrm{mg})$ at $t_{\mathrm{R}} 25 \mathrm{~min}$.

\subsection{Spectral Data}

Urdamycin $N 1$ (1). Dark red powder; $[\alpha]_{\mathrm{D}}^{20}+24\left(\right.$ c $\left.0.05, \mathrm{CDCl}_{3}\right) ; \mathrm{UV}\left(\mathrm{CDCl}_{3}\right) \lambda_{\max }(\log \varepsilon) 240$ (4.06), 285 (4.27), 411 (3.69); IR $v_{\max } 3391,2932,1705,1667,1632,1582,1492,1364,1279,1061,1011$, $754 \mathrm{~cm}^{-1} ;{ }^{1} \mathrm{H}$ NMR $\left(500 \mathrm{MHz}, \mathrm{CDCl}_{3} / \mathrm{CD}_{3} \mathrm{OD}\right)$ and ${ }^{13} \mathrm{C} \mathrm{NMR}\left(125 \mathrm{MHz}, \mathrm{CDCl}_{3} / \mathrm{CD}_{3} \mathrm{OD}\right)$ data, Table 1; (-)HR-ESI-MS $m / z$ 725.2834 ([M - H] $]^{-}$, calcd for $\left.\mathrm{C}_{38} \mathrm{H}_{45} \mathrm{O}_{14}, 725.2815\right)$.

Urdamycin N2 (2). Dark green powder; $[\alpha]_{\mathrm{D}}^{20}+235\left(c 0.06, \mathrm{CDCl}_{3}\right) ; \mathrm{UV}\left(\mathrm{CDCl}_{3}\right) \lambda_{\max }(\log \varepsilon) 241$ (4.62), 263 (4.55), 324 (4.71), 434 (4.17), IR $v_{\max } 3379,2926,1631,1504,1435,1300,1061,1011,758 \mathrm{~cm}^{-1}$; ${ }^{1} \mathrm{H}$ NMR $\left(700 \mathrm{MHz}\right.$, DMSO- $\left.d_{6}\right)$ and ${ }^{13} \mathrm{C}$ NMR $\left(176 \mathrm{MHz}\right.$, DMSO- $\left.d_{6}\right)$ data, Table 1 ; (-)HR-ESI-MS $\mathrm{m} / \mathrm{z}$ $707.2708\left([\mathrm{M}-\mathrm{H}]^{-}\right.$, calcd for $\left.\mathrm{C}_{38} \mathrm{H}_{43} \mathrm{O}_{13}, 707.2709\right)$.

Urdamycin N3 (3). Dark green powder; $[\alpha]_{\mathrm{D}}^{20}-430\left(c 0.04, \mathrm{CDCl}_{3}\right) ; \mathrm{UV}\left(\mathrm{CDCl}_{3}\right) \lambda_{\max }(\log \varepsilon) 240$ (4.48), 263 (4.39), 324 (4.55), 433 (4.02), IR $v_{\max } 3360,2920,1630,1506,1435,1229,1090,1057,772 \mathrm{~cm}^{-1}$; ${ }^{1} \mathrm{H}$ NMR $\left(700 \mathrm{MHz}\right.$, DMSO- $\left.d_{6} / \mathrm{CD}_{3} \mathrm{OD}\right)$ and ${ }^{13} \mathrm{C}$ NMR $\left(176 \mathrm{MHz}\right.$, DMSO- $\left.d_{6} / \mathrm{CD}_{3} \mathrm{OD}\right)$ data, Table 1 ; (-)HR-ESI-MS $m / z 463.1409$ ([M - H] $]^{-}$, calcd for $\mathrm{C}_{26} \mathrm{H}_{23} \mathrm{O}_{8}, 463.1398$ ).

Urdamycin N4 (4). Dark green powder; $[\alpha]_{\mathrm{D}}^{20}+125\left(c 0.06, \mathrm{CDCl}_{3}\right) ; \mathrm{UV}\left(\mathrm{CDCl}_{3}\right) \lambda_{\max }(\log \varepsilon) 207$ (3.92), 240 (4.16), 263 (4.05), 323 (4.18), 434 (3.67), IR $v_{\max }$ 3397, 2930, 1628, 1437, 1298, 1096, 1061, 1013, 852, $786 \mathrm{~cm}^{-1} ;{ }^{1} \mathrm{H}$ NMR $\left(500 \mathrm{MHz}\right.$, DMSO- $\left.d_{6} / \mathrm{CD}_{3} \mathrm{OD}\right)$ and ${ }^{13} \mathrm{C}$ NMR $\left(125 \mathrm{MHz}, \mathrm{DMSO}-d_{6} / \mathrm{CD}_{3} \mathrm{OD}\right)$ data, Table 2; (-)HR-ESI-MS $m / z$ $693.2554\left([\mathrm{M}-\mathrm{H}]^{-}\right.$, calcd for $\mathrm{C}_{37} \mathrm{H}_{41} \mathrm{O}_{13}$, 693.2553).

Urdamycin N5 (5). Dark green powder; $[\alpha]_{\mathrm{D}}^{20}+250\left(c 0.01, \mathrm{CDCl}_{3}\right) ; \mathrm{UV}\left(\mathrm{CDCl}_{3}\right) \lambda_{\max }(\log \varepsilon) 240$ (4.98), 322 (4.85), 437 (4.46), IR $v_{\max } 3392,2924,1626,1435,1267,1061,1013,773 \mathrm{~cm}^{-1} ;{ }^{1} \mathrm{H}$ NMR $(700 \mathrm{MHz}$, DMSO- $\left.d_{6} / \mathrm{CD}_{3} \mathrm{OD}\right)$ and ${ }^{13} \mathrm{C}$ NMR $\left(176 \mathrm{MHz}\right.$, DMSO- $\left.d_{6} / \mathrm{CD}_{3} \mathrm{OD}\right)$ data, Table 2 ; (-)HR-ESI-MS $\mathrm{m} / z$ $677.2606\left([\mathrm{M}-\mathrm{H}]^{-}\right.$, calcd for $\left.\mathrm{C}_{37} \mathrm{H}_{41} \mathrm{O}_{12}, 677.2604\right)$.

Urdamycin N6 (6). Red powder; $[\alpha]_{\mathrm{D}}^{20}+325\left(\right.$ c 0.06, $\left.\mathrm{CDCl}_{3}\right) ; \mathrm{UV}\left(\mathrm{CDCl}_{3}\right) \lambda_{\max }(\log \varepsilon) 219$ (4.57), 257 (4.19), 291 (4.04), 325 (3.67), 454 (3.90), IR $v_{\max } 3379,2928,1614,1435,1246,1086,752 \mathrm{~cm}^{-1} ;{ }^{1} \mathrm{H}$ NMR $(700 \mathrm{MHz}$, $\left.\mathrm{CDCl}_{3}\right)$ and ${ }^{13} \mathrm{C}$ NMR $\left(176 \mathrm{MHz}, \mathrm{CDCl}_{3}\right)$ data, Table 2; (-)HR-ESI-MS $m / z 495.1667\left([\mathrm{M}-\mathrm{H}]^{-}\right.$, calcd for $\mathrm{C}_{27} \mathrm{H}_{27} \mathrm{O}_{9}$, 495.1661).

Urdamycin N7 (7). Red powder; $[\alpha]_{\mathrm{D}}^{20}+130\left(c 0.06, \mathrm{CDCl}_{3}\right)$; UV $\left(\mathrm{CDCl}_{3}\right) \lambda_{\max }(\log \varepsilon) 218(4.50), 259$ (4.13), 284 (4.03), 325 (3.64), 451 (3.85), IR $v_{\max }$ 3360, 2918, 1612, 1435, 1238, 1086, 1060, $756 \mathrm{~cm}^{-1}$; ${ }^{1} \mathrm{H} \mathrm{NMR}\left(700 \mathrm{MHz}, \mathrm{CDCl}_{3}\right)$ and ${ }^{13} \mathrm{C}$ NMR $\left(176 \mathrm{MHz} \mathrm{CDCl}_{3}\right)$ data, Table 3; (-)HR-ESI-MS $\mathrm{m} / \mathrm{z} 495.1675$ ([M - H $]^{-}$, calcd for $\left.\mathrm{C}_{27} \mathrm{H}_{27} \mathrm{O}_{9}, 495.1661\right)$.

Urdamycin N8 (8). Red powder; $[\alpha]_{\mathrm{D}}^{20}+75\left(c 0.04, \mathrm{CDCl}_{3}\right) ; \mathrm{UV}\left(\mathrm{CDCl}_{3}\right) \lambda_{\max }(\log \varepsilon) 240(4.39), 266$ (4.27), 465 (3.91), IR $v_{\max } 3379,2932,1612,1435,1238,1057,1009,748 \mathrm{~cm}^{-1} ;{ }^{1} \mathrm{H}$ NMR $\left(700 \mathrm{MHz}, \mathrm{CDCl}_{3}\right)$ and ${ }^{13} \mathrm{C}$ NMR $\left(176 \mathrm{MHz}, \mathrm{CDCl}_{3}\right)$ data, Table 3; (-)HR-ESI-MS $m / z$ 739.2984 ([M - H $]^{-}$, calcd for $\mathrm{C}_{39} \mathrm{H}_{47} \mathrm{O}_{14}$, 739.2971). 
Urdamycin N9 (9). Red powder; $[\alpha]_{\mathrm{D}}^{20}+233\left(c 0.04, \mathrm{CDCl}_{3}\right) ; \mathrm{UV}\left(\mathrm{CDCl}_{3}\right) \lambda_{\max }(\log \varepsilon) 240(4.31), 265$ (4.28), 296 (4.08), 472 (3.94), IR $v_{\max } 3395,2932,1614,1435,1369,1248,1088,1059,1010.7,756 \mathrm{~cm}^{-1}$; ${ }^{1} \mathrm{H}$ NMR $\left(700 \mathrm{MHz}, \mathrm{CDCl}_{3}\right)$ and ${ }^{13} \mathrm{C}$ NMR $\left(176 \mathrm{MHz}, \mathrm{CDCl}_{3}\right)$ data, Table 3; (-)HR-ESI-MS $\mathrm{m} / z$ z39.2974 $\left([\mathrm{M}-\mathrm{H}]^{-}\right.$, calcd for $\left.\mathrm{C}_{39} \mathrm{H}_{47} \mathrm{O}_{14}, 739.2971\right)$.

Table 2. The ${ }^{1} \mathrm{H}$ and ${ }^{13} \mathrm{C}$ NMR data of compounds $4-6$ ( $\delta$ in ppm, $J$ in $\mathrm{Hz}$ ).

\begin{tabular}{|c|c|c|c|c|c|c|}
\hline \multirow{2}{*}{ Position } & \multicolumn{2}{|r|}{$4^{a}$} & \multicolumn{2}{|r|}{$5^{a}$} & \multicolumn{2}{|r|}{$6^{b}$} \\
\hline & $\delta_{\mathrm{C}}$ & $\delta_{\mathrm{H}}$ & $\delta_{\mathrm{C}}$ & $\delta_{\mathrm{H}}$ & $\delta_{\mathrm{C}}$ & $\delta_{\mathrm{H}}$ \\
\hline 1 & 155.4 & & 155.0 & & 157.1 & \\
\hline 2 & 119.6 & $6.97, \mathrm{~m}$ & 117.3 & $7.0, \mathrm{~s}$ & 126.0 & $6.73, \mathrm{~s}$ \\
\hline 3 & 139.7 & & 141.5 & & 144.0 & \\
\hline 4 & 114.4 & $7.63, \mathrm{~m}$ & 119.5 & $7.37, \mathrm{~s}$ & 123.0 & $6.89, \mathrm{~s}$ \\
\hline $4 a$ & 121.7 & & 138.6 & & 139.2 & \\
\hline 5 & 163.6 & & 135.4 & $8.22, \mathrm{~d}(8.5)$ & 78.1 & $4.23, \mathrm{~d}(2.8)$ \\
\hline 6 & 105.6 & $7.54, \mathrm{~s}$ & 121.5 & $8.18, \mathrm{~d}(8.5)$ & 70.2 & $4.91, \mathrm{~d}(2.8)$ \\
\hline $6 a$ & 136.5 & & 133.8 & & 141.6 & \\
\hline 7 & 188.7 & & 188.0 & & 189.1 & \\
\hline $7 a$ & 114.2 & & 114.4 & & 113.7 & \\
\hline 8 & 156.8 & & 156.7 & & 157.6 & \\
\hline 9 & 137.5 & & 136.8 & & 135.9 & \\
\hline 10 & 133.6 & $7.8, \mathrm{~m}$ & 133.5 & $7.86, \mathrm{~d}(7.8)$ & 133.0 & $7.88, \mathrm{~d}(7.9)$ \\
\hline 11 & 120.2 & $7.71, \mathrm{~m}$ & 118.7 & $7.67, \mathrm{~d}(7.8)$ & 121.4 & $7.80, \mathrm{~d}(7.9)$ \\
\hline $11 \mathrm{a}$ & 134.3 & & 134.5 & & 131.5 & \\
\hline 12 & 184.6 & & 186.8 & & 189.0 & \\
\hline $12 \mathrm{a}$ & 130.4 & & 134.4 & & 143.0 & \\
\hline $12 \mathrm{~b}$ & 122.1 & & 119.9 & & 112.9 & \\
\hline 13 & 21.1 & $2.40, \mathrm{~s}$ & 21.1 & $2.45, \mathrm{~s}$ & 21.4 & $2.34, \mathrm{~s}$ \\
\hline 14 & & & & & 58.5 & $3.45, \mathrm{~s}$ \\
\hline 15 & & & & & 56.7 & $3.26, \mathrm{~s}$ \\
\hline $1^{\prime}$ & 70.6 & $4.78, \mathrm{dd}(11.1,3.0)$ & 70.5 & $4.83, \mathrm{~d}(11.4)$ & 71.4 & $4.92, \mathrm{~d}(11.0)$ \\
\hline \multirow[t]{2}{*}{$2^{\prime}$} & 40.0 & $1.36, \mathrm{dd}(22.4,11.2)$ & 39.5 & $1.35, \operatorname{td}(11.9,9.9)$ & 39.5 & $1.46, \mathrm{dd}(23.8,11.7)$ \\
\hline & & $2.02, \mathrm{dd}(12.2,5.0)$ & & 2.01, ddd $(12.2,5.0,1.5)$ & & $2.54, \mathrm{dd}(12.1,3.9)$ \\
\hline $3^{\prime}$ & 74.9 & 3.69 , ddd $(11.2,9.0,4.9)$ & 74.9 & 3.70, ddd $(11.1,8.9,4.8)$ & 73.2 & $3.85, \mathrm{~m}$ \\
\hline $4^{\prime}$ & 74.8 & $3.05, \mathrm{t}(9.0)$ & 74.7 & $3.06, \mathrm{t}(8.9)$ & 78.2 & $3.21, t(8.9)$ \\
\hline $5^{\prime}$ & 76.4 & $3.48, \mathrm{~m}$ & 76.3 & 3.48 , overlapped & 76.0 & $3.53, \mathrm{dt}(15.1,6.1)$ \\
\hline $6^{\prime}$ & 18.6 & $1.29, \mathrm{~d}(6.0)$ & 18.5 & $1.30, \mathrm{~d}(6.1)$ & 18.2 & $1.42, \mathrm{~d}(6.1)$ \\
\hline $1^{\prime \prime}$ & 92.4 & $4.89, \mathrm{~m}$ & 92.2 & $4.89, \mathrm{~d}(2.7)$ & & \\
\hline \multirow[t]{2}{*}{$2^{\prime \prime}$} & 24.3 & $1.27, \mathrm{~m}$ & 24.2 & $1.26, \mathrm{~m}$ & & \\
\hline & & $1.84, \mathrm{~m}$ & & $1.83, \mathrm{~m}$ & & \\
\hline $3^{\prime \prime}$ & 24.3 & $1.77, \mathrm{~m} ; 1.96, \mathrm{~m}$ & 24.2 & $1.77, \mathrm{~m} ; 1.95, \mathrm{~m}$ & & \\
\hline $4^{\prime \prime}$ & 75.7 & $3.44, \mathrm{~m}$ & 75.6 & 3.44 , overlapped & & \\
\hline $5^{\prime \prime}$ & 65.6 & $4.15, \mathrm{q}(6.5)$ & 65.5 & $4.15, \mathrm{q}(6.4)$ & & \\
\hline $6^{\prime \prime}$ & 17.1 & $1.05, \mathrm{~d}(6.5)$ & 17.0 & $1.04, \mathrm{~d}(6.4)$ & & \\
\hline $1^{\prime \prime \prime}$ & 101.3 & $4.47, \mathrm{~d}(9.6)$ & 101.2 & $4.47, \mathrm{~d}(9.7)$ & & \\
\hline $2^{\prime \prime \prime}$ & 36.3 & $1.23, \mathrm{~m} ; 2.46, \mathrm{~m}$ & 36.2 & $1.24, \mathrm{~m} ; 2.47, \mathrm{~m}$ & & \\
\hline $3^{\prime \prime \prime}$ & 70.6 & $3.32, \mathrm{~m}$ & 70.5 & 3.33 , ddd $(11.8,8.7,5.1)$ & & \\
\hline $4^{\prime \prime \prime}$ & 77.0 & $2.72, \mathrm{t}(8.8)$ & 76.9 & $2.72, \mathrm{t}(8.7)$ & & \\
\hline $5^{\prime \prime \prime}$ & 71.8 & $3.1, \mathrm{~m}$ & 71.7 & $3.1, \mathrm{~m}$ & & \\
\hline $6^{\prime \prime \prime}$ & 18.3 & $1.14, \mathrm{~d}(6.2)$ & 18.2 & $1.14, \mathrm{~d}(6.1)$ & & \\
\hline
\end{tabular}

Table 3. ${ }^{1} \mathrm{H}$ and ${ }^{13} \mathrm{C}-\mathrm{NMR}$ data of compounds 7-9 in $\mathrm{CDCl}_{3}$ ( $\delta$ in ppm, $J$ in $\mathrm{Hz}$ ).

\begin{tabular}{ccccccc}
\hline \multirow{2}{*}{ Position } & \multicolumn{2}{c}{$\mathbf{7}$} & \multicolumn{3}{c}{$\mathbf{8}$} & $\mathbf{9}$ \\
\cline { 2 - 7 } & $\delta_{\mathrm{C}}$ & $\delta_{\mathrm{H}}$ & $\delta_{\mathrm{C}}$ & $\delta_{\mathrm{H}}$ & $\delta_{\mathrm{C}}$ & $\boldsymbol{\delta}_{\mathrm{H}}$ \\
\hline 1 & 156.5 & & 156.5 & & 157.1 & \\
2 & 120.6 & $6.81, \mathrm{~s}$ & 120.6 & $6.81, \mathrm{~s}$ & 126.0 & $6.73, \mathrm{~s}$ \\
3 & 145.4 & & 145.4 & & 144.0 & \\
4 & 119.0 & $7.17, \mathrm{~s}$ & 119.0 & $7.16, \mathrm{~s}$ & 123.0 & $6.89, \mathrm{~s}$ \\
$4 \mathrm{a}$ & 138.8 & & 138.8 & & 139.5 & \\
5 & 80.0 & $4.27, \mathrm{~d}(2.2)$ & 80.0 & $4.27, \mathrm{~d}(2.5)$ & 78.1 & $4.23, \mathrm{~d}(2.9)$ \\
6 & 67.4 & $4.99, \mathrm{~d}(3.1)$ & 67.4 & $4.99, \mathrm{~d}(3.1)$ & 70.2 & $4.91, \mathrm{~d}(2.9)$ \\
$6 \mathrm{a}$ & 140.2 & & 140.2 & & 141.6 & \\
7 & 189.0 & & 188.9 & & 189.1 & \\
\hline
\end{tabular}


Table 3. Cont.

\begin{tabular}{|c|c|c|c|c|c|c|}
\hline \multirow{2}{*}{ Position } & \multicolumn{2}{|r|}{7} & \multicolumn{2}{|r|}{8} & \multicolumn{2}{|r|}{9} \\
\hline & $\delta_{\mathrm{C}}$ & $\delta_{\mathrm{H}}$ & $\delta_{\mathrm{C}}$ & $\delta_{\mathbf{H}}$ & $\delta_{\mathrm{C}}$ & $\delta_{\mathrm{H}}$ \\
\hline $7 a$ & 113.6 & & 113.5 & & 113.7 & \\
\hline 8 & 157.6 & & 157.7 & & 157.7 & \\
\hline 9 & 139.4 & & 139.7 & & 135.9 & \\
\hline 10 & 133.2 & $7.90, \mathrm{~d}(7.9)$ & 133.2 & $7.89, \mathrm{~d}(7.9)$ & 133.0 & $7.87, \mathrm{~d}(7.8)$ \\
\hline 11 & 121.5 & $7.80, \mathrm{~d}(7.9)$ & 121.5 & $7.78, \mathrm{~d}(7.9)$ & 121.4 & $7.79, \mathrm{~d}(7.8)$ \\
\hline $11 \mathrm{a}$ & 131.3 & & 131.3 & & 131.4 & \\
\hline 12 & 188.7 & & 188.8 & & 189.0 & \\
\hline $12 \mathrm{a}$ & 143.1 & & 143.2 & & 143.0 & \\
\hline $12 b$ & 112.5 & & 112.5 & & 112.9 & \\
\hline 13 & 21.9 & $2.36, \mathrm{~s}$ & 21.9 & $2.36, \mathrm{~s}$ & 21.4 & $2.34, \mathrm{~s}$ \\
\hline 14 & 58.2 & $3.69, \mathrm{~s}$ & 58.2 & $3.69, \mathrm{~s}$ & 58.5 & $3.44, \mathrm{~s}$ \\
\hline 15 & 59.3 & $3.42, \mathrm{~s}$ & 59.3 & $3.41, \mathrm{~s}$ & 56.7 & $3.26, \mathrm{~s}$ \\
\hline $1^{\prime}$ & 71.4 & $4.94, \mathrm{~d}(11.0)$ & 71.3 & $4.89, \mathrm{dd}(9.5,1.1)$ & 71.4 & $4.87, \mathrm{~d}(10.4)$ \\
\hline \multirow[t]{2}{*}{$2^{\prime}$} & 39.4 & $1.46, \mathrm{~d}(12.1)$ & 37.7 & $1.48, \mathrm{~d}(11.7)$ & 37.7 & $1.47, \mathrm{~m}$ \\
\hline & & $2.53, \mathrm{dd}(12.7,3.5)$ & & $2.48, \mathrm{~m}$ & & 2.50, ddd $(13.0,4.9,1.7)$ \\
\hline $3^{\prime}$ & 73.2 & $3.87, \mathrm{~m}$ & 82.4 & 3.72, ddd $(11.6,8.3,5.1)$ & 82.5 & 3.71, ddd $(11.5,8.3,5.1)$ \\
\hline $4^{\prime}$ & 78.2 & $3.22, \mathrm{t}(8.9)$ & 76.3 & $3.18, \mathrm{t}(8.7)$ & 76.3 & $3.18, \mathrm{t}(8.7)$ \\
\hline $5^{\prime}$ & 76.1 & $3.54, \mathrm{dt}(15.1,6.0)$ & 76.3 & $3.51, \mathrm{td}(12.2,6.1)$ & 76.3 & $3.51, \mathrm{q}(6.0)$ \\
\hline $6^{\prime}$ & 18.2 & $1.43, \mathrm{~d}(6.1)$ & 18.6 & $1.44, \mathrm{~d}(6.0)$ & 18.6 & $1.44, \mathrm{~d}(6.0)$ \\
\hline $1^{\prime \prime}$ & & & 97.9 & $5.04, \mathrm{~s}$ & 98.0 & $5.03, \mathrm{~s}$ \\
\hline \multirow[t]{2}{*}{$2^{\prime \prime}$} & & & 25.3 & $1.55, \mathrm{~d}(13.9)$ & 25.4 & $1.54, \mathrm{~d}(13.8)$ \\
\hline & & & & $2.15, \mathrm{~m}$ & & $2.13, \mathrm{~m}$ \\
\hline \multirow[t]{2}{*}{$3^{\prime \prime}$} & & & 24.7 & $1.95, \mathrm{~m}$ & 24.7 & $1.96, \mathrm{~m}$ \\
\hline & & & & $2.13, \mathrm{~m}$ & & $2.13, \mathrm{~m}$ \\
\hline $4^{\prime \prime}$ & & & 76.1 & $3.55, \mathrm{~m}$ & 76.1 & $3.55, \mathrm{~m}$ \\
\hline $5^{\prime \prime}$ & & & 67.7 & $4.13, \mathrm{dd}(12.9,6.4)$ & 67.7 & $4.13, \mathrm{q}(6.0)$ \\
\hline $6^{\prime \prime}$ & & & 17.2 & $1.24, \mathrm{~d}(6.5)$ & 17.1 & $1.23, \mathrm{~d}(6.5)$ \\
\hline $1^{\prime \prime \prime}$ & & & 101.5 & $4.55, \mathrm{dd}(9.5,1.1)$ & 101.5 & $4.52, \mathrm{dd}(9.6,1.6)$ \\
\hline \multirow[t]{2}{*}{$2^{\prime \prime \prime}$} & & & 39.3 & $1.71, \mathrm{dd}(21.9,12.1)$ & 39.3 & $1.71, \operatorname{td}(12.1,9.9)$ \\
\hline & & & & $2.30, \mathrm{dd}(12.5,5.0)$ & & 2.29, ddd $(12.4,4.9,1.5)$ \\
\hline $3^{\prime \prime \prime}$ & & & 71.7 & $3.59, \mathrm{~m}$ & 71.7 & $3.59, \mathrm{~m}$ \\
\hline $4^{\prime \prime \prime}$ & & & 77.7 & $3.11, \mathrm{t}(8.9)$ & 77.7 & $3.11, \mathrm{t}(8.9)$ \\
\hline $5^{\prime \prime \prime}$ & & & 72.0 & $3.26, \mathrm{dq}(9.1,6.1)$ & 72.0 & $3.24, \mathrm{~m}$ \\
\hline $6^{\prime \prime \prime}$ & & & 17.9 & $1.31, \mathrm{~d}(6.1)$ & 17.9 & $1.31, \mathrm{~d}(6.2)$ \\
\hline
\end{tabular}

\subsection{Electronic Circular Dichroism (ECD) Calculation}

Monte Carlo conformational searches were carried out by means of the Spartan's 10 software (Wavefunction, Inc., Irvine, CA, USA) using Merck Molecular Force Field (MMFF). The conformers with Boltzmann-population of over $5 \%$ were chosen for electronic circular dichroism (ECD) calculations, and then the conformers were initially optimized at B3LYP/6-31+g $(d, p)$ level in methanol using the conductor-like polarizable continuum model (CPCM). The theoretical calculation of ECD was conducted in methanol using Time-dependent Density functional theory (TD-DFT) at the B3LYP/6-311+g (d, p) level for all conformers of compounds 6 and 7. Rotatory strengths for a total of 10 excited states were calculated. ECD spectra were generated using the program SpecDis 1.6 (University of Würzburg, Würzburg, Germany) and GraphPad Prism 5 (University of California San Diego, San Diego, CA, USA) from dipole-length rotational strengths by applying Gaussian band shapes with sigma $=0.3 \mathrm{eV}$.

\section{Conclusions}

The early report of urdamycin derivatives, urdamycins A-F, were isolated from Streptomyces fradiae Tu 2717 by Drautz in 1986. Since then, many urdamycin congeners were discovered. Structurally, urdamycins have different aglycone parts, whereas the sugar moieties are always the same [10]. Most of them were decorated with a trisaccharide chain composed of $\beta$-olivose- $(1 \rightarrow 4)-\alpha-$ rhodinose-( $(1 \rightarrow 3)-\beta$-olivose via a C-C linkage. Diverse biological activities of these angucycline antibiotics were evaluated, and the most important were their cytotoxicities against the tumor cell lines. At the same time, this potent cytotoxicity also limited their use in the clinic. In this study, nine new 
angucycline glycosides, urdamycin N1-N9 (1-9), together with two known congener urdamycins A (10) and B (11) were obtained from a mangrove-derived Streptomyces diastaticus subsp. SCSIO GJ056. Compounds 7 and 8 are the first naturally occurring $(5 R, 6 R)$ angucycline glycosides. We will further investigate the biological activity of these new angucycline compounds.

Supplementary Materials: The following are available online at http:/ /www.mdpi.com/1660-3397/16/6/185/s1. This section includes 1D, 2D NMR spectra for new compounds 1-9, and computational details of 6 and 7.

Author Contributions: C.G. performed the experiments and wrote the draft manuscript. Y.L. performed the ECD calculations. Z.Z. and S.Z. contributed to the isolation and identification of compounds. Y.H. provided the strain. H.H. revised the manuscript. Y.-C.G. and J.J. supervised the whole work, and edited the manuscript. All authors read and approved the final manuscript.

Funding: This research was funded by the National Natural Science Foundation of China [grant numbers 41476133, 81425022, and U1501223], the Program of Chinese Academy of Sciences [grant number XDA11030403], and the Natural Science Foundation of Guangdong Province [grant number 2016A030312014].

Acknowledgments: We thank Syngenta Ph.D. Fellowship Awarded to Chun Gui. We are grateful to Zhihui Xiao, Aijun Sun, Yun Zhang and Chuanyun Li in the analytical facility at SCSIO for recording spectroscopic data.

Conflicts of Interest: The authors declare no conflict of interest.

\section{References}

1. Rohr, J.; Thiericke, R. Angucycline group antibiotics. Nat. Prod. Rep. 1992, 9, 103-137. [CrossRef] [PubMed]

2. Kharel, M.K.; Pahari, P.; Shepherd, M.D.; Tibrewal, N.; Nybo, S.E.; Shaaban, K.A.; Rohr, J. Angucyclines: Biosynthesis, mode-of-action, new natural products, and synthesis. Nat. Prod. Rep. 2012, 29, $264-325$. [CrossRef] [PubMed]

3. Zhang, Y.; Huang, H.; Chen, Q.; Luo, M.; Sun, A.; Song, Y.; Ma, J.; Ju, J. Identification of the grincamycin gene cluster unveils divergent roles for GcnQ in different hosts, tailoring the L-rhodinose moiety. Org. Lett. 2013, 15, 3254-3257. [CrossRef] [PubMed]

4. Hertweck, C.; Luzhetskyy, A.; Rebets, Y.; Bechthold, A. Type II polyketide synthases: Gaining a deeper insight into enzymatic teamwork. Nat. Prod. Rep. 2007, 24, 162-190. [CrossRef] [PubMed]

5. Song, Y.; Liu, G.; Li, J.; Huang, H.; Zhang, X.; Zhang, H.; Ju, J. Cytotoxic and antibacterial angucyclineand prodigiosin-analogues from the deep-sea derived Streptomyces sp. SCSIO 11594. Mar. Drugs 2015, 13, 1304-1316. [CrossRef] [PubMed]

6. Lai, Z.; Yu, J.; Ling, H.; Song, Y.; Yuan, J.; Ju, J.; Tao, Y.; Huang, H. Grincamycins I-K, cytotoxic angucycline glycosides derived from marine-derived actinomycete Streptomyces lusitanus SCSIO LR32. Planta Med. 2018, 84, 201-207. [CrossRef] [PubMed]

7. Zhu, X.; Duan, Y.; Cui, Z.; Wang, Z.; Li, Z.; Zhang, Y.; Ju, J.; Huang, H. Cytotoxic rearranged angucycline glycosides from deep sea-derived Streptomyces lusitanus SCSIO LR32. J. Antibiot. 2017, 70, 819-822. [CrossRef] [PubMed]

8. Rohr, J.; Zeeck, A. Metabolic products of microorganisms. 240. Urdamycins, new angucycline antibiotics from Streptomyces fradiae. II. Structural studies of urdamycins B to F. J. Antibiot. 1987, 40, 459-467. [CrossRef] [PubMed]

9. Ren, X.; Lu, X.; Ke, A.; Zheng, Z.; Lin, J.; Hao, W.; Zhu, J.; Fan, Y.; Ding, Y.; Jiang, Q.; et al. Three novel members of angucycline group from Streptomyces sp. N05WA963. J. Antibiot. 2011, 64, 339-343. [CrossRef] [PubMed]

10. Drautz, H.; Zähner, H.; Rohr, J.; Zeeck, A. Metabolic products of microorganisms. 234 Urdamycins, new angucycline antibiotics from Streptomyces fradiae. J. Antibiot. 1986, 39, 1657-1669. [CrossRef] [PubMed]

11. Zeeck, A.; Rohr, J.; Sheldrick, G.M.; Jones, P.G.; Paulus, E.F. Structure of a new antibiotic and cytotoxic indicator substance, urdamycin A. J. Chem. Res. 1986, 104-105.

12. Pérez, M.; Schleissner, C.; Rodríguez, P.; Zúñiga, P.; Benedit, G.; Sánchez-Sancho, F.; de la Calle, F. PM070747, a new cytotoxic angucyclinone from the marine-derived Saccharopolyspora taberi PEM-06-F23-019B. J. Antibiot. 2009, 62, 167-169. [CrossRef] [PubMed]

13. Hong, S.T.; Carney, J.R.; Gould, S.J. Cloning and heterologous expression of the entire gene clusters for PD 116740 from Streptomyces strain WP 4669 and tetrangulol and tetrangomycin from Streptomyces rimosus NRRL 3016. J. Bacteriol. 1997, 179, 470-476. [CrossRef] [PubMed] 
14. Mori, K.; Ohmori, K.; Suzuki, K. Stereochemical relay via axially chiral styrenes: Asymmetric synthesis of the antibiotic TAN-1085. Angew. Chem. Int. Ed. Engl. 2009, 48, 5633-5637. [CrossRef] [PubMed]

15. Mori, K.; Tanaka, Y.; Ohmori, K.; Suzuki, K. Synthesis and stereochemical assignment of angucycline antibiotic, PD-116740. Chem. Lett. 2008, 37, 470-471. [CrossRef]

16. Ohmori, K.; Mori, K.; Ishikawa, Y.; Tsuruta, H.; Kuwahara, S.; Harada, N.; Suzuki, K. Concise total synthesis and structure assignment of TAN-1085. Angew. Chem. Int. Ed. Engl. 2004, 43, 3167-3171. [CrossRef] [PubMed]

17. Hauser, F.M.; Dorsch, W.A.; Mal, D. Total synthesis of ( \pm )-O-methyl PD 116740. Org. Lett. 2002, 4, 2237-2239. [CrossRef] [PubMed]

(C) 2018 by the authors. Licensee MDPI, Basel, Switzerland. This article is an open access article distributed under the terms and conditions of the Creative Commons Attribution (CC BY) license (http://creativecommons.org/licenses/by/4.0/). 